\title{
The Development of State Civil Apparatus
}

\author{
Muhammad Eko Atmojo \\ Government Studies Departement \\ Universitas Muhammadiyah Yogyakarta \\ Yogyakarta, Indonesia \\ muhammadekoatmojo@yahoo.com
}

\author{
Nur Khaerah \\ Government Studies Departement \\ Universitas Muhammadiyah Makassar \\ Makassar, Indonesia \\ Nurkhaerah.unismuh@gmail.com
}

\author{
Dyah Mutiarin \\ Master of Government Affairs and Administration \\ Universitas Muhammadiyah Yogyakarta \\ Yogyakarta, Indonesia \\ mutiarin@yahoo.com
}

\begin{abstract}
Human resources problems in Indonesia are: the distribution of civil servants who are has not been spread evenly based on competence, and there is still much accumulation of civil servants in areas city. This study attempts to describe and assess the role of regional employee agency special region of Yogyakarta in the implementation of the civil development servants. This research uses a qualitative methodology, by which objects of execution in this research is the regional employee agency particular region (Badan Kepegawaian Daerah) of Yogyakarta that is one best practices in developing civil servants. Therefore, can get civil servants who are competent and professional in carrying out their duties. Findings from the study show that local employee agency regional of Yogyakarta expand employees through some things of them are as follows: education and training (DIKLAT), rotation and position promotion.
\end{abstract}

Keywords - Governance, human resources, public service, developing civil servants.

\section{INTRODUCTION}

In the era of regional autonomy has to bring large implication for Indonesia, especially in the field of human resources. Since the implementation of regional autonomy, there are a lot of happened increase in the number of employees, which a burden budget for civil servants was increasing and scope of the authority also wider. In order to readiness in national employment affairs management is good, clearly need time, and the quality of human resources are reliable. Therefore, human resources development in the macro is essential in order to realise the goals of development effectively. Zulchaidir [1] and Irfan [2]. They encourage the creation of the mission of organisation/government agencies that is the quality of service employees provided to the public. To realise the quality of services for the public than necessary resources officers competent and professional. Professionalism employees will be formed if the recruitment employees based on competence, that can produce employees possess the capacity and fine quality.

In 2011 Indonesia had the number of civil servants about 4,5 million employees (BadanPusatStatistik). The number of civil servants who big it turns out that not yet made the significant effect on public services. Rosyadi [3] argue that personnel expenditure civil servants tended to improve and have used the public budget that hinders the implementation of various development programs socioeconomic. In outline human resources problem in Indonesia can be described as follows: the disparity in the distribution of civil servants, Wahiyuddin [4], the recruitment powers of appointment and the transfer of, as well as training for a career civil servants very not paying attention to the principle of competence, however, be based on the political consideration.

In addition to improving the quality of human resources through education and training not directed in the analysis/ the needs of the work unit. This condition causes not deficient output or outcome of the implementation of education and training for improving the employee performance and organization. Meanwhile, in the development of career employees also often without rested on professionalism (merit system), but more seniority or other considerations. This kind of things that ultimately caused training or development employees, especially civil servants, absorbing not maximal.

Besides not at the development of civil servants so many cities that recruited civil servants is not based on the needs and competence. Winarsih [5] said that to anticipate an increase in the number of employees should the recruiting employee who have formation competence by its work there. Therefore, will cause maintain a harmony between competence required by an office with competence owned by employees.

Yogyakarta is one of the areas best practices in the development of resources apparatus, one of them in development in position promotion. The implementation of the position promotion in the special Yogyakarta has innovation own the assessment center. This is what made development employees in local government special region of Yogyakarta as a best practice. Besides becoming best practices in developing resources apparatus, Yogyakarta also became one of the areas with index human development highest number two after Jakarta. This indicates that governance resources apparatus in the special region of Yogyakarta was 
quite optimal. From explaining the writer would like outline the role of regional employee agency in the development of employees in the special region of Yogyakarta.

\section{RESEARCH METHODOLOGY}

This study adopted qualitative approaches. using a qualitative methodology because the data collected and the analysis more qualitative [6]. This study will be carried out in human resources agency (Badan Kepegawaian Daerah) and the consideration promotion (Badan Pertimbangan Jabatan dan Kepangkatan) of Special Region of Yogyakarta. The technique data collection in this research using observation non-participation, interview, and documentation. While data analyst uses the method Miles and Huberman in 2014, there is three kinds of data analyst model interactive that can be used, namely (a) reduction data; (b) the presentation of data; (c) draw conclusions /verification [7].

\section{RESEARCH FINDINGS \& DISCUSSION}

Management human resources are thing to do to fulfil needs organization. Resources apparatus is the most important things in an organization, life of an organization can be seen from resources apparatus or are civil servants. To manage civil servants so, each region has resources management institutions apparatus that is human resources agency (BadanKepegawaian Daerah). The task of Badan Kepegawaian Daerah is conducting the management of personnel administration, programs established and guidance, the development of human resources, and implement mutation and administration for human resources. The main tasks and a function of local employee board regarding the development of civil servants are covering planning and the development of employees, mutation human resources, guidance discipline, the welfare and administration of employees, training of administrative and activities.

The development of employees is very important to do any organization, which with the employees development and professionalism employees will increase. There are two things that must be considered in the development of civil servants quantity and quality. The problem of quantity this is concerning the total number of human resources. Quantity human resources have to be balanced with the quality of human resources good also. A quantity related to the quality of human resource which is emphasised the ability physical and non-physical. In other words, the quality of human resources is concerning two physical aspects and non-physical related to the ability work, reflect, and other skills [8].

A policy for developing for employees or resources apparatus must do so that the quality of resources apparatus will increase also factors the success of an organization seen from quality and quantity resources apparatus. Then Notoatmodjo [8] argue that there was two a concept in developing human resources are developing human resources in macro is a process of improving the quality or strengthening in order to achieve the development goals. While developing human resources in a planning process micro education, training and managing power or employees to achieve optimum results. The development of human resources apparatus covering education and training, and developing career employees the promotion. As for the purpose of education and training for employees is to improve the ability, professional by the competence of employees so as to bring impact on institutional development government concerned.

The development of employees through education and training is part of the development of the quality of employees. The purpose of education and training for employees is to improve the competence of employees and realize the civil servants who professional. Therefore, education and training also it is important for each employee and organization. Before the development of employees through education and training then BadanKepegawaian Daerah Yogyakarta Special Region will carry out some things of them are in training needs analysis, and group discussion forum (GDF). The development of employees through education and training in Special Region of Yogyakarta must be implemented with a base analysis kebutuhandiklat and GDF followed by all SKPD .Of this analysis so BadanKepegawaian Daerah only be expanded employees through education and training by recommendations analysis undertaken by BadanKepegawaian Daerah and all working units in the ranks of the local government of Yogyakarta. The purpose of held the GDF with SKPD is to find needs training for each SKPD, so that in the implementation of the education and training SKPD to be able to send they said in accordance with the main tasks and functions.With this indirectly SKPD can be recognized functions which has not yet run with maximum.As for education and training done by BadanKepegawaian Daerah Special Region of Yogyakarta as follows: first, education and training appointment training, second, education and training leadership, third, education and training technical.

Position promotion is a part of the development employees of more exactly is the development of a career for employees, that the promotion is a very important thing for employees to prevent balance the way organization. The development of employees does have a lot of models one of them is position promotion.The purpose of position promotion is to improve the ability and professional employees and improve confidence for employees. By the formation of employees professional and competent so development employees promotion must be based on merit system.

To realize employees competent and professional the management of position promotion, recruitment and removal of should use merit system. Where merit system more stress on removal of and promotion employees based on the competency and professional.Therefore BadanKepegawaian Daerah Special Region of Yogyakarta implement position promotion with several stages of them are selection administration, assessment center, the fit and proper tests, the fact integrity and evaluation every six months. While for the implementation of position promotion still many areas that uses system traditional and vulnerable to nepotism.

By maintaining competent employees and professional then Badan Kepegawaian Daerah Special Region of 
Yogyakarta expand employees including the development of the quality and development career. The development of quality only focused to education and training, besides the more promotion career office. It is must be done to achieve civil servants that competent and professional.

In advance of did the process of education and training BadanKepegawaian Daerah Special Region Of Yogyakarta will conduct analysis needs like (AKD) and forum group discussion (GDF) with all a unit of performance (SKPD).This was done to analyze the function of every local unit and no run with maximum, that could be done delivery employees to do education and training.The aim of education and training is to create resources officers have the ability in work well and professional.The development of employees through education and training to be distinguishable in several species of them are: education and training structural, education and training technical, education and training functional.

To create employees professional development Badan Kepegawaian Daerah not work alone in terms of education and training, where Badan Kepegawaian Daerah have a partnership with BANDIKLAT (Badan Diklat) at province.This cooperation is part of the process of education and training and in order to realize competent employees and professional.The development of employees through education and training is the most important to improve competence of employees and create employees professional.

By maintaining employees professional and competent then BadanKepegawaian Daerah expand employees through education and training and promotion office.Promotion office are part of the development for civil career.In the development of employees promotion the employment InSpecial Region of Yogyakarta first to be done through a bank data collection.The purpose of filtering is to make it easier to the potential, then in the assessment center will be easier to monitor.Selection criteria for employees across the data is as follows: track record of employees, the official discipline, a waiting list of employees (DaftarUrutPegawai) and list of nominative employees.

The process of development employees promotion the employment in Special Region ofYogyakarta different than other regions. The different promotion falsehood the employment in yogyakarta special region to other regions are the method assessment center for employees who will be promoted .Employees can follow the assessment centeris employees who qualify as follows: track record, notes discipline, a waiting list of employees (DaftarUrutPegawai) and list of nominative. A waiting list of employees (DaftarUrutPegawai )is based on the employees seniority, while nominative list is an arrangement of employees in agency or seen from the rank and work performance.

The process position promotion divided into two types of position promotion structural and position promotion regular. However, all process position promotion within the regions Special Region of Yogyakarta uses the assessment center.It is meant to identify the competence of employees so that employees be able to work with professional.Assessment center done two days followed 5-6 employees every stretch
out.During the process assessment center of employees will be viewed from the perspective of potential and competence.The following are the measurement of the competence of employees during in assessment center: employees will be will follow first to see knowledge in general and the potential employees; employees during assessment center will do leader group discussion (LGD), where in LGD assessors just saw and assess.The purpose of LGD is to see the leadership in employees; in basket is task for the echelon ii to disposition letter to servient; the problem analysis of the candidates second echelon structural officers in assessment were given a broken and problems to find the solution, so here is considered employees of the way break and find a solution to a problem.

After doing assessment center then the competence of employees can be seen based on value or result testing the competence of employees. Afterward, the implementation assessment center the assessors will be make a report based on the competency and potential luminance employees, in addition weakness and excess each employee will be used in the reports.The reports that had made will be given to BadanKepegawaian Daerah and BAPERJAKAT for consideration in the implementation of the position promotion.

Based on the results of assessment center then employees had the 3 large get opportunities to be promoted. However, this is different between position promotion regular with position promotion structural. The position promotion structural the employees had the rank 1st to 3 will follow selection next stage.Employees have index highest or rank 1 to 3 will be submitted to the governor to do the fit and proper tests.A method of the fit and proper tests this is the final competency test is before team BAPERJAKAT and the governor.The purpose of the fit and proper tests was only to get employees competent and professional, so that in implementing the tasks can effective and efficient.Based on the results of the fit and proper test and value judgments assessment center so governor will determine the suitability or otherwise employees to be promoted to structural office.

In addition to promoting the structural position of BKD, special region of Yogyakarta will also do an evaluation every 6 months. The purpose of this evaluation is to improve performance and creativity unit organizational performance the device region and officials concerned. The structural officials did not meet expectations in leading an organization then will be given other tasks deemed appropriate by the capabilities and competencies as well as in the field of the task or the rotation of the Office.

Here is a picture of the process of implementing the promotion of structural position in the local government of Yogyakarta.

Picture 1: Phases of structural position promotion in regional government of Yogyakarta 


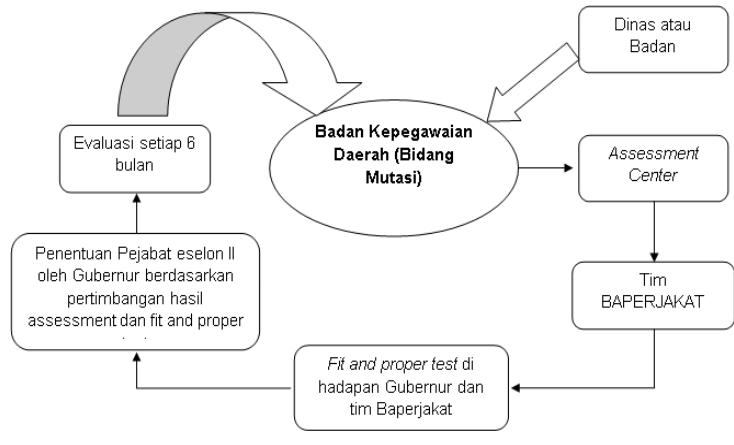

Source: The data analysis of research 2014

As for the promotion of regular employees who then would be seen based on the results of the assessment ceter. From the results of the assessment officers who ranked 1 to 3 or get the index value of the highest then it will be promoted to a higher position. It is a direct follow up the development of employees in the special region of Yogyakarta based on a merit system. It can be seen from the methods and process of promotion of the Office which operates to the competence of employees

\section{CONCLUSION}

Of several the above analysis that development employees have a lot of its shape from is education and training, position promotion, and rotation.In the implementation of the development employees in special region of Yogyakarta has been based on competence, this can be seen of the education and training that takes into account analysis needs training and implementation of position promotion with based on the results of assessment center and the fit and proper tests. Therefore, that the implementation of development employees in special region of Yogyakarta it can be said use merit system because based on with the competence of employees, this is done to realize employees competency and professional.

The implementation of the position promotion in Yogyakarta has a different level to other regions. Where the implementation of the promotion the employment in special region of Yogyakarta uses the assessment center and the fit and proper tests to see competence servant candidates. While other regions the implementation of the development employees through position promotion more a chink stress to a factor political or proximity. Should the implementation of the promotion be conducted by prioritising the achievement, the competency and professional so that was born employees competent and professional.Not only held assessment and the fit and proper tests Badan Kepegawaian Daerah of Yogyakarta also implement the fact integrity and evaluation every six months. The aim of promotion office with new innovations of this is to get civil servants who are competent and professional, then the deployment of employees in accordance with the competency and their field. This could run well because the commitment and support of the head of the region to realize civil servants who are competent and professional.

\section{REFERENCES}

[1] Zulchaidir (2011). Proses Rekrutmen Pimpinan Birokrasi Pemerintah daerah di Kabupaten Slemandan Kota Parepare. Jurnal Studi Pemerintahan: Vol, 2 No. 2 Agustus.

[2] Irfan, Muhlis (2002), Efektivitas Diklat Struktural Bagi Pegawai Negeri Sipil (Post Training Evaluation), Puslitbang BKN:Jakarta.

[3] Rosyadi, Slamet (2011). Problem Rekrutmen dan Seleksi Pegawai Negeri Sipil. Jurnal kebijakan dan Manajemen PNS, Vol , 5 No. 2 November.

[4] Wahiyuddin, Laode (2012). Politisasi Pejabat Struktural (Study Kasus Politisasi Pejabat Struktural Eselon II di Sekretariat Daerah Kabupaten Muna Sulawesi Tenggara). Tesis: Universitas Gajah Mada.

[5] Winarsih, Atik Septi \& Ratminto (2011). Penyusunan Sistem Perencanaan Karier Pemerintah Kabupaten Klaten, Jawa Tengah. JurnalStudiPemerintahan Volume 02 No 2 Agustus.

[6] Sugiyono, 2014. Metode Penelitian Kuantitatif, Kualitatif dan R\&D. Alfabeta: Bandung.

[7] Huberman, dan Miles, 2014. Analisis Data Kualitatif, Jakarta: Universitas Indonesia

[8] Notoatmodjo. Soekidjo (2009). Pengembangan Sumber Daya Manusia. PT Rineka Cipta: Jakarta. 